\title{
Harvest Active Recombinant Rho Kinase from Escherichia coli
}

\author{
Weigang Duan, Shanzhi Wang, Min Chen, Cuifen Wang, Luyong Zhang, ${ }^{*}$ Jun Liu, Lixin Sun, and \\ Ming YAN
}

Jiangsu Center for Drug Screening, China Pharmaceutical University; 1, Shennong Road, Nanjing 210038, P. R. China. Received August 4, 2005; accepted October 3, 2005

\begin{abstract}
Rho kinase (ROCK) inhibitors are effective candidates for treating nerve or myocardial injury, erectile dysfunction, and other cardiovascular diseases. Purified ROCK is a foundation for ROCK inhibitors screening and for its function research in vitro. This article established an easy way to harvest active recombinant ROCK catalytic domain (ROCK-CD) of rat in Escherichia coli $(E$. coli). The cDNA of ROCK-CD was amplified by RTPCR, and subcloned to pET28a(+) vector to express the protein in $E$. coli $\mathrm{BL}(21)$ as inclusion bodies. The protein was purified by HiTrap chelating column, and its refolding was achieved by gradient dilution from guanidine hydrochloride solution, and desalinated by ultrafiltration. The result of DNA sequencing and protein sequence analysis indicate there were three amino acid residua of mutation, but the activity was not significantly affected. The activity of the recombinant protein was confirmed by ROCK II activity fluorescence polarization kit. Therefore, this is an easy and rapid procedure to harvest a large quantity of activity recombinant ROCK-CD at low cost.
\end{abstract}

Key words rho-associated kinase; activity assay, recombination

Rho kinase, known as Rho-associated coiled-coil forming protein serine/threonine kinase (ROCK) ${ }^{1)}$ is one of the central regulatory molecules for cytoskeleton control and cell adhesion process. ${ }^{2}$ ROCK also involves in other cell functions such as apoptosis ${ }^{3)}$ and tumor invasiveness. ${ }^{4)}$ Rho kinase is thought to play an important role in a variety of cellar functions such as stress fiber formation, focal adhesion formation, cell aggregation, cell morphology, cytokinesis, cell migration, and $\mathrm{Ca}^{2+}$-sensitization in the smooth muscle. ${ }^{2,5}$ Recent report showed that Rho kinase involves in regulation of the amyloid precursor protein processing. ${ }^{6}$ ) ROCK inhibitors are beneficial candidates for a wide range of diseases such as hypertension, inflammation, cancer, ${ }^{4}$ erectile dysfunction, ${ }^{7}$ and injury caused by ischemia and reperfusion. ${ }^{8}$ )

There are two types of ROCK: ROCK-I (ROCK- $\beta$ ) mainly found in hepatocytes, and ROCK-II (ROCK- $\alpha$ ) in central nerve system (CNS). ROCK is activated by binding with the activated form of a low molecular weight $\mathrm{G}$ protein, Rho. ${ }^{9)}$ Purified ROCK is important foundation for understanding the full function of ROCK, and is very useful in ROCK inhibitors screening. Katoh et al. ${ }^{10)}$ have conformed that $1-$ 543 amino acid residua have catalytic function; further research suggested the kernel catalytic domain of ROCK (ROCK-CD) may be $92-354$ amino acid residua. ${ }^{11)}$ Turner et $a{ }^{12)}$ reported a way to harvest recombinant human ROCK-CD from $S f-21$ cell, which became a main purified ROCK source currently. However, this procedure is timeconsuming and at a relatively high cost; which makes its price relatively expensive. It is needed to improve a procedure to harvest the ROCK-CD at low price, at high quality, and at large quantity; harvesting active ROCK-CD from $E s$ cherichia coli (E. coli) may be the choice met the request.

\section{MATERIALS AND METHODS}

RT-PCR The cDNA encoding the amino acids 5-552 of rat ROCK-II was cloned with polymerase chain reaction (PCR) techniques. Primers were designed according to rat ROCK-II sequence NM_009072 in GenBank. ${ }^{11)}$ Briefly, Rat brain total RNA was extracted by TRIzol kit (Invitrogen, U.S.A.), cDNA was reverse transcribed by reverse transcriptase from rat brain total RNA. A partial cDNA fragment of rat ROCK-II, 1644 nt (13-1656) was amplified using Taq DNA Polymerase (Takara Biotech, Japan) with $10 \mathrm{pm}$ of each primer (cycling conditions: $94^{\circ} \mathrm{C}$ for $60 \mathrm{~s}, 55^{\circ} \mathrm{C}$ for $60 \mathrm{~s}$, $72{ }^{\circ} \mathrm{C}$ for $90 \mathrm{~s}, 30$ cycles, finally kept at $72{ }^{\circ} \mathrm{C}$ for $20 \mathrm{~min}$ ). Primer A was 5'-ATGAGCGGATCCCCGCCGACGGGGAAAAT-3' and primer B was 5'-ACCTCTCTCGAGTATCTGAGAGCTCTGGT-3' (the underline in primer A is BamHI site; and in primer B is Xholl site).

The PCR-amplified fragment was subcloned into pGEM-T Easy Vector (Promega, U.S.A.). Then, the cDNA of ROCK$\mathrm{CD}$ was sequenced by the vector and confirmed as the encoding 5-552 amino acids.

Positive Clone Screening ROCK-CD cDNA in pGEM$\mathrm{T}$ Easy Vector was digested with BamHI and XhoI and ligated into $\mathrm{pET} 28 \mathrm{a}(+)$ expression vector (Novagen, U.S.A.). The pET28a $(+)$ contains a (His)6-tag at its N-terminus. The expressed protein is a $67.4 \mathrm{kDa}$ fusion protein by calculation.

Two micrograms of ligated pET28a $(+)$ was transferred to $2 \mathrm{ml}$ E. coli $\mathrm{BL}(21)$ with the help of $\mathrm{CaCl}_{2}$ treatment. Promising clones were selected by $30 \mu \mathrm{g} / \mathrm{ml}$ kanamycin.

Promising clones were induced by $1 \mathrm{~mm}$ isopropy- $\beta$-Dthiogalactoside (IPTG); clones that expressed proteins were screened by routine $10 \%$ SDS-PAGE. The promising clones that were able to express a new $67.4 \mathrm{kDa}$ protein were recognized as positive clones. The (His)6-tag of the protein was also used for identification and purification by HiTrap chelating column (Amersham Biosciences, Sweden).

Positive Clone Culture Positive BL(21) clones were cultured in LB culture media (tryptone $10 \mathrm{~g} / \mathrm{l}$; yeast extraction $5 \mathrm{~g} / \mathrm{l} ; 10 \mathrm{~g} / \mathrm{l}$ of $\mathrm{NaCl}$ ) containing $30 \mu \mathrm{g} / \mathrm{ml}$ kanamycin, at $37^{\circ} \mathrm{C}, 200 \mathrm{rpm}$ in a rocking incubator. When the absorbance $(600 \mathrm{~nm}, 1 \mathrm{~cm})$ of the culture media is about 0.8 , different doses of IPTG were exposed to, and the temperature and rotation speed were adjust to room temperature and $100 \mathrm{rpm}$ respectively. After the clones were induced for $0-12 \mathrm{~h}$, the bacteria were isolated by centrifugation $\left(4^{\circ} \mathrm{C}, 12000 \times \boldsymbol{g}, 5\right.$ 
$\min )$.

Protein Extraction and Purification The ROCK-CD protein of rat (rROCK) was expressed as inclusion bodies, and the extraction was carried out as follow. Briefly, the bacteria from $100 \mathrm{ml}$ were suspensed in $4 \mathrm{ml}$ Suspense Buffer $(20 \mathrm{~mm}$ TrisHCl, pH 7.5$)$, and was sonicated $(300 \mathrm{~W}, 10 \mathrm{~s}$ sonication, $10 \mathrm{~s}$ interval, 30 cycles) on ice. The precipitation was got by centrifugation $\left(12000 \times \boldsymbol{g}, 4^{\circ} \mathrm{C}, 10 \mathrm{~min}\right)$ and resuspensed in $4 \mathrm{ml}$ Resuspense Buffer ( $20 \mathrm{~mm}$ TrisCl, $0.2 \mathrm{M}$ $\mathrm{NaCl}, 2 \mathrm{~m}$ urea, $1 \mathrm{~mm}$ 2-mercaptoethanol, 2\% Triton X-100, $\mathrm{pH} 7.5)$. The second sonication $(300 \mathrm{~W}, 10 \mathrm{~s}$ sonication, $10 \mathrm{~s}$ interval, 20 cycles) was carried out and the precipitation was obtained by centrifugation $\left(12000 \times \mathbf{g}, 4^{\circ} \mathrm{C}, 10 \mathrm{~min}\right)$. Purified inclusion bodies were obtained by rinsing the precipitation twice with Resuspense Buffer without Triton X-100. The inclusion bodies were dissolved in $4 \mathrm{ml}$ Degeneration Buffer $(20 \mathrm{~mm}$ TrisCl, $0.2 \mathrm{M} \mathrm{NaCl}, 0.05 \mathrm{M}$ imidazole, $6 \mathrm{M}$ guanidine hydrochloride, $1 \mathrm{~mm}$ 2-mercaptoethanol, $\mathrm{pH} 7.5$ ) by vertex at room temperature for about $15 \mathrm{~min}$. After removed remaining particles by passing the sample through a $0.22 \mu \mathrm{m}$ filter, the purification procedure followed.

HiTrap chelating $1 \mathrm{ml}$ column was washed with $5 \mathrm{ml}$ purified water using a $5 \mathrm{ml}$ syringe. Load $0.5 \mathrm{ml} 0.1 \mathrm{M} \mathrm{NiSO}_{4}$ and continue to wash with $5 \mathrm{ml}$ purified water. Equilibrate the column with $5 \mathrm{ml}$ Degeneration Buffer. Then Load the sample and wash the column with $10 \mathrm{ml}$ Degeneration Buffer and with $5 \mathrm{ml}$ Elution Buffer ( $20 \mathrm{~mm}$ TrisCl, $0.2 \mathrm{M} \mathrm{NaCl}, 0.5 \mathrm{M}$ imidazole, $1 \mathrm{~mm}$ 2-mercaptoethanol, $\mathrm{pH}$ 7.5). The Elution Buffer (containing rROCK-CD) was fractionally collected and stored at $-20^{\circ} \mathrm{C}$ for detection and refolding.

Refolding of rROCK-CD Let the Elution Buffer thawed at room temperature. rROCK-CD protein was separated by centrifugation $\left(12000 \times \mathbf{g}, 4^{\circ} \mathrm{C}, 10 \mathrm{~min}\right)$. Two milligrams precipitation was dissolved in $200 \mu \mathrm{l}$ Degeneration Buffer without imidazol. The refolding was accomplished by diluting the solution to about $2 \mathrm{ml}$ with purified water very slowly on ice. Guanidine hydrochloride was removed by ultrafiltration (10 $\mathrm{kDa}$ ultrafiltration tub, Millipore). rROCK-CD solution was adjusted to $1 \mathrm{mg} / \mathrm{ml}\left(20 \mathrm{~mm}\right.$ TrisHCl, $20 \mathrm{~mm} \mathrm{MgCl}_{2}, 1 \mathrm{~mm}$ 2-mercaptoethanol, $0.56 \% \mathrm{NaN}_{3}, \mathrm{pH}$ 7.2) and stored at $-70{ }^{\circ} \mathrm{C}$. The protein concentration was determined by Coomassie brilliant blue assay kit (Nanjing Jiancheng Bioengineering Institute, China).

rROCK-CD Activity Assay The activity of the protein was verified by ROCK assay fluorescence polarization (FP) kit (Molecular Devices Company, U.S.A.). This kit uses $200 \mathrm{~nm}$ S6-derived fluorescence peptide as its substrate; the phosphorylated peptide can bind to a macromolecule, and the flueroscence varies from low FP to high FP according to the amount of the phosphorylated substrate. The FP was detected by Tecan Reader (Megallan, Swiss). Comparison of rROCKCD activity was made with standard $63.3 \mathrm{kDa}$ human ROCKCD (hROCK-CD) (purchased from Upstate Company, U.S.A.). The steady-rate constants, $K_{\mathrm{m}}$ and $K_{\text {cat }}$, and $\mathrm{IC}_{50}$ of Y-27632 (purchased from Alexis Biochemicals, U.S.A.) were determined also by the assay kit followed the methods of ref. 13. $\mathrm{IC}_{50}$ of Y-27632 was calculated by Bliss Method. ${ }^{14)}$

\section{RESULTS}

RT-PCR of rROCK-CD The RT-PCR product was de-
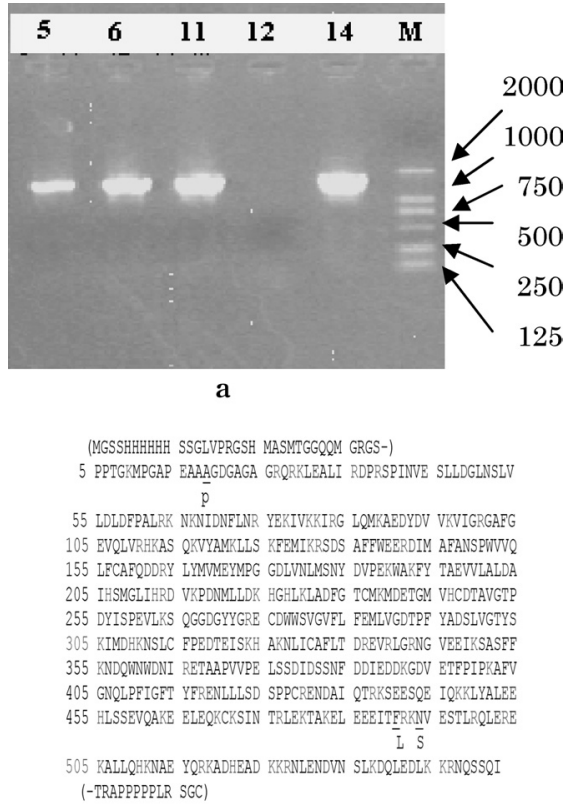

b

Fig. 1. Result of RT-PCR, and Protein Analysis

RT-PCR fragment was detected by $0.8 \%$ agarose electrophoresis, the fragment is $1644 \mathrm{nt}$ (a). The cDNA sequence indicated that RT-PCR generated three amino acid residua mutation $\left(\mathrm{P}_{18} \rightarrow \mathrm{A}, \mathrm{L}_{490} \rightarrow \mathrm{F}, \mathrm{S}_{493} \rightarrow \mathrm{N}\right)$. The mutated amino acid residua were underlined, beneath which were original amino acid residua. Sequence before or after rROCK-CD sequence was fusion protein segment from $\mathrm{pET} 28 \mathrm{a}(+)$ vector

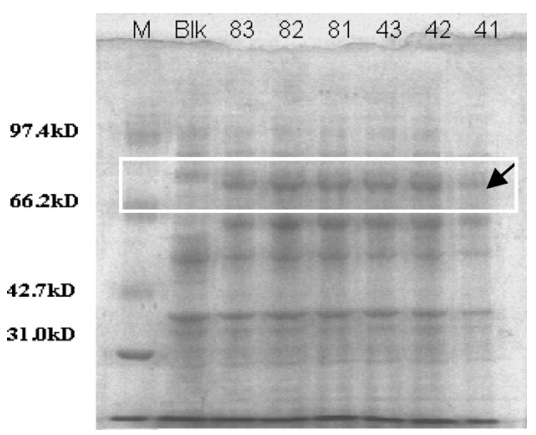

Fig. 2. Positive Clone Screening by $10 \%$ SDS-PAGE

Six positive clones were screened. Clones with $r$ ROCK-CD ${ }^{+}$pET28a( + ) vector was able to express a new protein about $67.4 \mathrm{kDa}(83,82,81,43,42,41)$ induced by IPTG, but clone with rROCK-CD-pET28a(+) can't (Blk). The target protein was shown in the white square.

tected by $0.8 \%$ agarose electrophoresis (Fig. 1a), which indicated the product could be the sequence of $1644 \mathrm{nt}$. The result of sequencing indicated that there are three sites $\left(\mathrm{P}_{18} \rightarrow\right.$ $\mathrm{A}, \mathrm{L}_{490} \rightarrow \mathrm{F}, \mathrm{S}_{493} \rightarrow \mathrm{N}$ ) of mutation in amino acid sequence from visual translation (Fig. 1b). The recombinant protein (including fusion fragment from vector) is about $67.4 \mathrm{kDa}$ by calculation (Fig. 1b).

Positive Clone Selection Promising clones were induced by IPTG; their protein were extracted and detected by $10 \%$ SDS-PAGE. Figure 2 indicated that six positive clones appeared, since a new protein of about $67.4 \mathrm{kDa}$ were induced compared to the negative clone. In order to verify the result, the vector in the E. coli was extracted and amplified by PCR with the same pair of primers under the same conditions, and the result of PCR was the same as showed in Fig. 1a. 
Optimization of rROCK-CD Expression and Extraction In order to increase the yields and save the time of the whole procedure, conditions of expression and extraction were optimized. Figure $3 \mathrm{a}$ showed that it takes only $3-6 \mathrm{~h}$ for the positive clones to express the maximal yield of the protein at room temperature. And the experiment (Fig. 3b) indicates that the positive clones exposed to $0.1-0.5 \mathrm{~mm}$ IPTG were enough to induce the maximal yield.

Refolding of rROCK-CD The Elution Buffer contained rROCK-CD as high as $1 \mathrm{mg} / \mathrm{ml}$. 10\% SDS-PAGE detection indicated that there are almost no contaminated proteins in the final product (Fig. 4a), and the purity was thought to be

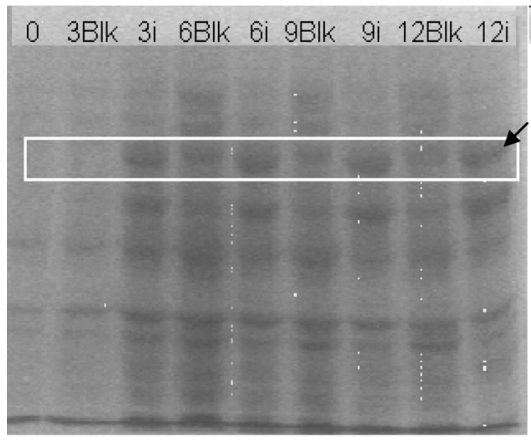

Fig. 3. Conditions Optimization of rROCK-CD Expression and Extraction

(a) The protein induced by $1 \mathrm{~mm}$ IPTG in positive clone for different time. A positive clone induced for $0,3,6,9$, or $12 \mathrm{~h}$, but when induced for 3 or $6 \mathrm{~h}$, the yield attained maximum. (Blk is abbreviation for "blank"; i for "induced by IPTG") (b) Protein induced by IPTG of different doses $(0-1.0 \mathrm{~mm})$. Positive clone exposed to about $0.1-0.5 \mathrm{~mm}$ IPTG is enough to express the protein. The target protein was shown in the white squares.
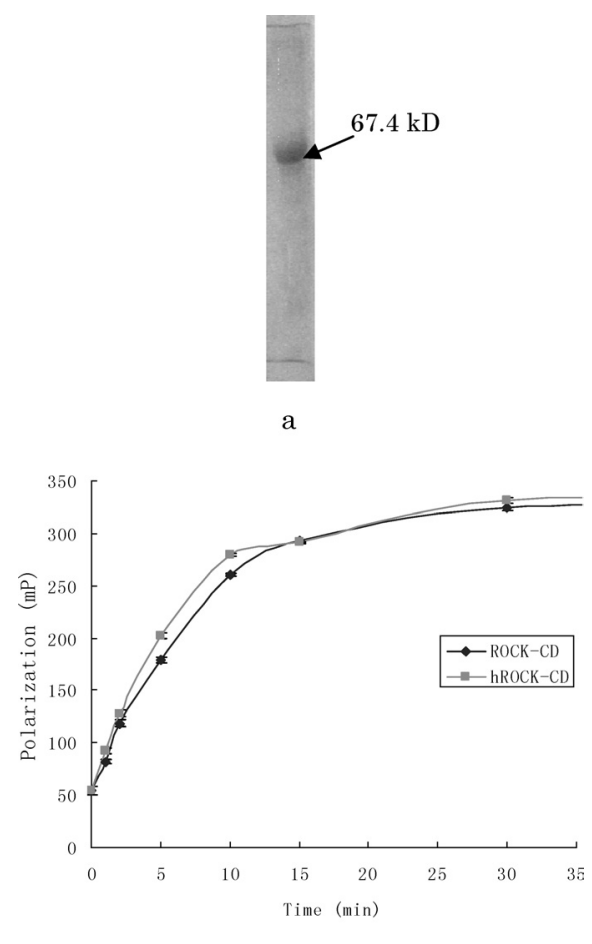

b

Fig. 4. ROCK Purity Detection and Result of Recombinant ROCK Activity

(a) rROCK-CD detected by $10 \%$ SDS-PAGE after purified by HiTrap chelating column, desalinated by ultrafiltration. (b) rROCK-CD was assayed with ROCK activity assay FP kit compared to hROCK-CD (standard ROCK-CD) (mean \pm S.D., $n=3$ ). Condition: $37^{\circ} \mathrm{C}, 2 \mu \mathrm{g} / \mathrm{ml}$ enzyme, $200 \mathrm{~nm}$ S6-derived peptide, $10 \mu \mathrm{M}$ ATP. of no less than $95 \%$. More than $2 \mathrm{mg}$ of final product can be obtained from $1000 \mathrm{ml}$ culture media.

rROCK-CD Activity Assay The activity of refolded rROCK-CD was assayed by ROCK assay FP kit. The result in Fig. $4 \mathrm{~b}$ showed that the activity of the rROCK-CD was similar to that of hROCK-CD. The steady-state rate constants of rROCK-CD were measured by ROCK activity assay FP kit compared with hROCK-CD. The constants were similar to those of hROCK-CD showed in Table 1.

Because urea and guanidine hydrochloride were applied in this procedure, it is needed to elucidate what concentration of

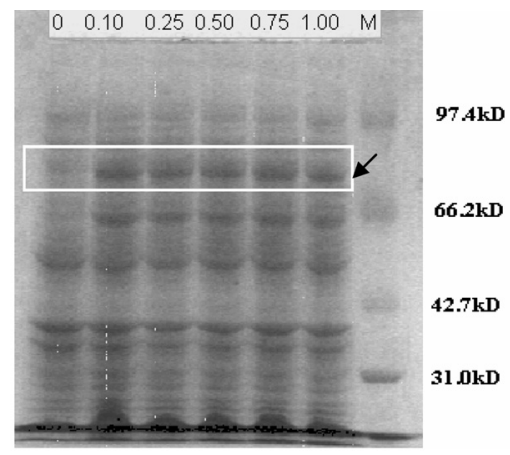

$\mathrm{b}$ the two denaturing agents are tolerable in its work solution.

Table 1. Steady-State Rate Constants of rROCK-CD for S6-Derived Peptide Compared with hROCK-CD

\begin{tabular}{cccc}
\hline \hline Enzyme & $K_{\text {cat }}\left(\min ^{-1}\right)$ & $K_{\mathrm{m}}(\mu \mathrm{M})$ & $K_{\mathrm{cat}} / K_{\mathrm{m}}\left(\mathrm{min}^{-1} \mu \mathrm{M}^{-1}\right)$ \\
\hline rROCK-CD & $73.8 \pm 5.8$ & $1.05 \pm 0.14$ & $70.3 \pm 0.8$ \\
hROCK-CD & $77.3 \pm 9.0$ & $1.06 \pm 0.20$ & $72.9 \pm 1.8$ \\
\hline
\end{tabular}

Kinetic parameters were calculated from the Michaelis $\cdot$ Menten equation using Lineweaver-Burk analysis. ${ }^{13)}$ Conditions: $37^{\circ} \mathrm{C}, 25$ pm enzyme, $200 \mathrm{~nm}$ S6-derived peptide, 15 min reaction (mean \pm S.D., $n=3$ ).

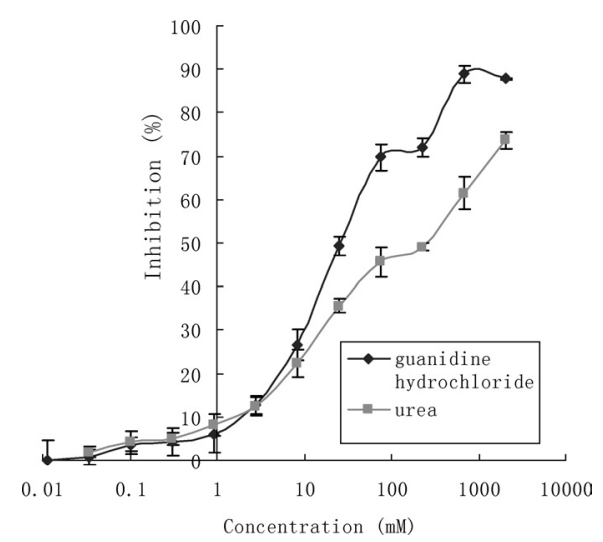

Fig. 5. Urea or Guanidine Hydrochloride Inhibition on rROCK-CD

rROCK-CD is sensitive to urea in a dose-dependence manner, and is more sensitive to guanidine hydrochloride. Conditions: $37^{\circ} \mathrm{C}, 25 \mathrm{pm}$ enzyme, $200 \mathrm{~nm}$ S6-derived peptide, $10 \mu \mathrm{M}$ ATP, 30 min reaction (mean \pm S.D., $n=3$ ). 
Figure 5 showed that rROCK-CD is sensitive to urea or guanidine hydrochloride, but at low concentration (below $1 \mathrm{~mm}$ ), guanidine hydrochloride almost has little effects on rROCK-CD, so does urea.

Inhibition of rROCK-CD ROCK selective inhibitor, Y27632 , inhibited activity of both rROCK and hROCK in a dose-dependent manner in the activity assay system, the pattern of them and $\mathrm{IC}_{50}(0.26 \pm 0.02 \mu \mathrm{M}$ for rROCK-CD, and $0.35 \pm 0.02 \mu \mathrm{M}$ for hROCK-CD) were similar showed in Fig. 6.

\section{DISCUSSION}

ROCK is a central enzyme associated in many cell functions, the catalytic domain which was recognized to be the first 543 amino acid residua. ${ }^{10)}$ Other domains (including Rho Binding Domain) in ROCK regulate the catalytic activity. ROCK inhibitors, like Y-27632 and fasudil, ${ }^{15)}$ can selectively bind to the catalytic domain and inhibit its activity. ROCK inhibitors were regarded as promising choice to treat nerve injury, ${ }^{16)}$ myocardial injury, ${ }^{8)}$ erectile dysfunction, ${ }^{7)}$ and other diseases. Therefore, purified ROCK-CD, as an executive domain, is very useful in screening ROCK inhibitors and studying ROCK function in vitro.

Turner et ll $^{12)}$ have developed a method to harvest recombinant ROCK-CD of human (hROCK-CD) from $S f-21$ cell, but the cost is relatively high and the procedure is time-consuming. Katoh et al. ${ }^{10)}$ had tried to recombine rat ROCK-CD in $E$. coli in their experiment, but there are no further reports could verify whether this method is feasible. Usually, recombinant eukaryotic protein expressed in prokaryote like E. coli would give rise to mis-folding, although this kind of expression give a very high yield. Refolding recombinant protein in $E$. coli as inclusion bodies sometimes was proved to be a formidable task because of the low refolding efficiency.

Fortunately, the purification and refolding of rROCK-CD are not as difficult as we thought. The yield of (His)6-tagged rROCK-CD expressed in E. coli is more than $2 \mathrm{mg}$ in 1000 $\mathrm{ml}$ culture as inclusion bodies, the yield is about once more than that of Turner et al. ${ }^{12)}$ Our data also indicated that there are almost no contaminated proteins in the final product (Fig. 4a). The refolding procedure was proved to be simple and effective. The gradient dilution for refolding should keep very slow, especially at the beginning; and should dilute to no less than 10 times. There are several successful examples which used the similar procedure from inclusion bodies. ${ }^{17,18)}$

The activity curve in Fig. 5 showed similar property of rROCK-CD and hROCK-CD. Usually, the parameters of kinase were obtained by isotope. Present study used FP assay kit to determine the parameters. The classical selective substrates for ROCK are myosin light chain, ${ }^{19)}$ and myosin light chain phosphatase, ${ }^{20)}$ which regulate actin contraction. Trauger's report ${ }^{21)}$ suggested that S6-derived peptide is also one of selective substrates for ROCK, and conformed by Turner et al. ${ }^{12)}$ The constants of hROCK (Table 1) and $\mathrm{IC}_{50}$ of Y-27632 were similar to Turner's report, ${ }^{12)}$ which suggested the FP assay system is effective and feasible to determine ROCK activity. Compared with hROCK-CD, the parameters of rROCK-CD (including activity, $K_{\mathrm{m}}, K_{\text {cat }}$, and $\mathrm{IC}_{50}$ of Y-27632) based on the activity assay system were also similar; which indicated that the purified rROCK-CD could

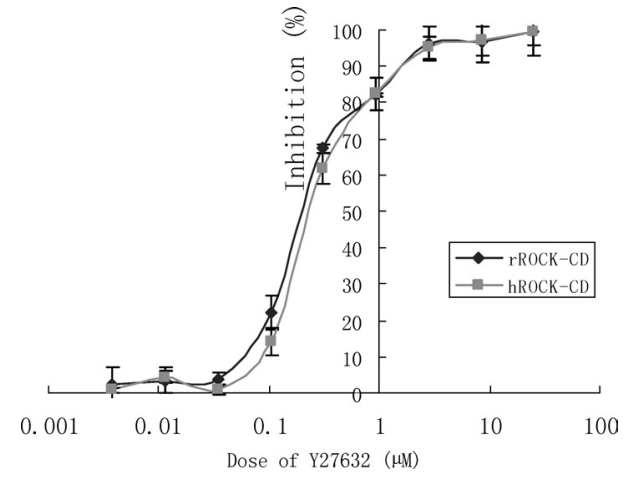

Fig. 6. rROCK-CD Activity Inhibited by Y-27632

Y-27632 inhibited rROCK-CD and hROCK-CD in a dose-dependent manner. The inhibition curves were similar. The $\mathrm{IC}_{50}$ were calculated by Bliss method, ${ }^{14)} 0.26 \pm 0.02$ $\mu \mathrm{M}$ for rROCK-CD and $0.35 \pm 0.02 \mu \mathrm{M}$ for hROCK-CD in the assay system. Conditions: $37^{\circ} \mathrm{C}, 25 \mathrm{pm}$ enzyme, $200 \mathrm{~nm}$ S6-derived peptide, $10 \mu \mathrm{M}$ ATP, 30 min reaction (mean \pm S.D., $n=3$ )

be used for drug screening or further activity research.

In order to refold the protein as inclusion bodies, urea or guanidine hydrochloride is usually applied. Present study showed rROCK-CD is sensitive to both of them. Urea and guanidine hydrochloride can be removed by ultrafiltration. Our data (Fig. 5) indicated that, if urea or guanidine hydrochloride was controlled below $1 \mathrm{~mm}$ in work solution, the interference is omissible (inhibition $<10 \%$ or $5 \%$ ); which indicate that the degenerative reagent needn't remove thoroughly on some occasions.

In the present study, RT-PCR introduced three amino acid residua mutation $\left(\mathrm{P}_{18} \rightarrow \mathrm{A}, \mathrm{L}_{490} \rightarrow \mathrm{F}, \mathrm{S}_{493} \rightarrow \mathrm{N}\right)$. For these mutated amino acids were far away from the kernel sequence of rROCK catalytic domain (92-354 amino acid), ${ }^{11)}$ if there were discount of activity of rROCK-CD, it would not be significant; which confirmed by activity assay.

Taken together, an easy and rapid procedure was established to harvest a large quantity of active recombinant rROCK-CD at low cost from E. coli; the convenience of the procedure is obvious.

Acknowledgements The study is supported by Megaproject of Science Research for the 10th Five-year Plan (No. 2004AA2Z3785) of Ministry of Science and Technology of P. R. China.

\section{REFERENCES}

1) Ishizaki T., Maekawa M., Fujisawa K., Okawa K., Iwamatsu A., Fujita A., Watanabe N., Saito Y., Kakizuka A., Morii N., Narumiya S., EMBO J., 15, 1885-1893 (1996).

2) Fukata Y., Amano M., Kaibuchi K., Trends Pharmacol. Sci., 22, 32 39 (2001).

3) Sebbagh M., Hamelin J., Bertoglio J., Solary E., Breard J., J. Exp. Med., 201, 465-471(2005).

4) Sun B., Nishihira J., Yoshiki T., Kondo M., Sato Y., Sasaki F., Todo S., Clin. Cancer Res., 11, 1050-1058 (2005).

5) Akiko M., Sui H., Kimberly M., Philmo O., Donald E. I., J. Biol. Chem., 279, 26323-26330 (2004).

6) Zhou Y., Su Y., Baolin L., Ryder J. W., Xin W., Gonzalez-DeWhitt P. A., Gelfanova V., Hale J. E., May P. C., Paul S. M., Binhui N., Science, 302, 1215-1217 (2003).

7) Mills T. M., Lewis R. W., Wingard C. J., Linder A. E., Jin L., Webb R. C., Int. J. Impot. Res., 15 (Suppl. 5), S20-S24 (2003).

8) Weike B., Erding H., Ling T., Rogely B., Rosanna M., Douglas T., 
Thudiumd, Xin-ling M., Robert N., Willette A., Tian-li Y., Cardiovasc. Res., 61, 548-558 (2004).

9) Kawano Y., Fukata Y., Oshiro N., Amano M., Nakamura T., Ito M., Matsumura F., Inagaki M., Kaibuchi K., J. Cell Biol., 147, 10231038 (1999).

10) Katoh H., Aoki J., Ichikawa A., Negishi M., J. Biol. Chem., 273, 2489-2492 (1998).

11) Nakagawa O., Fujisawa K., Ishizaki T., Saito Y., Nakao K., Narumiya S., FEBS Lett., 392, 189-193 (1996).

12) Turner M. S., Lin F. F., Trauger J. W., Stephens J., LoGrasso P., Arch Biochem. Biophys., 405, 13-20 (2002).

13) Chen S. G., Zhou R. Q., "Enzymology," Fudan University Press, Shanghai, 2001.

14) Sun R. Y., "Quantity Pharmacology," People's Medical Publishing House, Beijing, 1987.
15) Suzuki Y., Yamamoto M., Wada H., Ito M., Nakano T., Sasaki Y., Narumiya S., Shiku H., Nishikawa M., Blood, 93, 3408-3417(1999).

16) Fournier A. E., Takizawa B. T., Strittmatter S. M., J. Neurosci., 23, 1416 - 1423 (2003).

17) Chunsheng M., Hongbin S., Jizhi L., Changming Y., Haitao W., Mianyixue Zazhi, 15, 229-231 (1999).

18) Lili W., Xindu G., Hua H., Chinese J. Cell Mol. Immunol., 20, 402405 (2004).

19) Kimura K., Ito M., Amano M., Chihara K., Fukata Y., Nakafuku M., Yamamori B., Feng J., Nakano T., Okawa K., Iwamatsu A., Kaibuchi K., Science, 273, 245-248 (1996).

20) Essler M., Amano M., Kruse H. J., Kaibuchi K., Weber P. C., Aepfelbacher M., J. Biol. Chem., 273, 21867-21874 (1998).

21) Trauger J. W., Lin F. F., Turner M. S., Stephens J., LoGrasso P. V., Biochemistry, 41, 8948-8953 (2002). 